\title{
A época das revoluções no contexto do tacitismo: notas sobre a primeira tradução portuguesa dos Anais
}

\author{
The Age of Revolutions in the context of Tacistism: \\ some remarks on the firs portuguese translation \\ of Tacitus'Annals
}

Valdei Lopes de Araujo*

Resumo: Neste artigo analisamos alguns temas do tacitismo, enquanto linguagem político-historiográfica disponível para significar as profundas transformações vivenciadas pelo mundo luso-brasileiro entre 1808 e 1830 . Atenção especial é dedicada ao estabelecimento das condições de produção da primeira tradução portuguesa dos Anais de Tácito, vertida por José Liberato Freire de Carvalho entre 1811 e 1813 e publicada entre 1820 e 1830.

Palavras-chave: Tacitismo. Historiografia. Independência do Brasil.

Abstract: This paper analyses some themes of tacitism. These themes are here approached as a political and historiographical language available to signify the political and social changes that took place in the Luso-brazilian world between 1808 and 1830. Special attention is given to the study of the first Portuguese translation of Tacitus' Annals undertake by José Liberato Freire de Carvalho between 1811 and 1813 and published between 1820 and 1830 .

Keywords: Tacitism. Historiography. Brazilian Independence.

Um dos traços da consciência histórica em sua fase clássica é a percepção de que a representação da história deve coincidir com a própria história; e que o conhecimento da história é uma das condições de seu acontecer. Talvez essa circularidade nos ajude a entender a força

\footnotetext{
* Professor de História da Historiografia na UFOP, membro do Núcleo de Pesquisa em História da Historiografia e Modernidade - NEHM. Bolsista do Programa Pesquisador Mineiro da Fapemig e Pesquisador do CNPq.
} 
cognitiva que emerge nos grandes períodos comemorativos; neles podemos identificar momentos de esgotamento dessa conjunção entre a representação da história e seu acontecer. Assim, não é por acaso que o cronótopo moderno encontre um dos seus momentos de crise na revisão motivada pelas comemorações do bicentenário da Revolução Francesa. Entre 1789 e 1889, o mundo ocidental organizou a experiência do tempo em torno de elementos centrais da meta-história liberal: nação, civilização, evolução, razão e indivíduo. No século seguinte, esses conceitos foram explorados até seus limites, de modo que, em 1989, a Revolução Francesa já não poderia ser evocada apenas como a origem mítica de nosso mundo.

A historiografia dos processos de Independência da América parece seguir nessa mesma direção, com um grande esforço de releitura da experiência da colonização e formação dos Estados-nacionais. Com a crise das grandes narrativas, esses eventos voltaram a exibir certa opacidade, perderam o seu caráter fundador e tornaram-se fonte de disputa historiográfica. O próprio tema da revolução perdeu sua carga normativa na avaliação desses fatos. Antes, a sensação de estarmos vivendo em uma continuidade com essa história - éramos a sua realização seja como nacionalidade em formação, seja como homens modernos - gerava uma transparência que autorizava que medíssemos esse passado pelo que ele viria a ser: nós mesmos. Assim, entendemos a concentração das análises em problemas como modernização, nação e revoluções incompletas. Buscavam-se as raízes desses fracassos, mas sempre de posse de definições muito sólidas do que deveria ser ou ter sido a revolução, a modernidade ou a nação verdadeiras. Todos esses temas retornam com força na historiografia contemporânea, mas enfraquecidos em seus traços normativos e ampliados na vontade de descrevê-los mais do que defini-los.

Neste artigo, procuro caminhar nessa mesma direção de um resgate da resistência do passado à sua incorporação como simples origem do presente. Assim, o texto foi divido em quatro partes. Nas duas primeiras, traço o horizonte teórico-metodológico no qual o objeto aqui estudado, "a linguagem do tacitismo", pode ser compreendido. Na terceira parte, faço um esforço, ainda preliminar, de caracterizar os temas dessa linguagem movimentados no contexto do fim do "Antigo Sistema Colonial" no Brasil, ou seja, 1808-1830. Na última parte, analiso as relações entre experiência histórica e a linguagem do tacitismo através da narrativa da produção da primeira tradução para o português dos Anais de Tácito. 


\section{Consequências teórico-metodológicas do Giro Linguístico para a Historiografia intelectual}

Podemos definir o Giro Linguístico como a crescente consciência das dimensões não representacionais da linguagem. Além de simplesmente descrever o mundo, a linguagem tem funções performativas, ou seja, comportam fenômenos como os atos de fala que produzem efeitos transformadores nos contextos em que são enunciados. Assim, podemos e devemos ler um texto não meramente em busca de seu sentido imediato, do que dizem suas palavras, frases e discursos, mas também enquanto acontecimentos históricos específicos cujo significado depende do momento de sua enunciação. Ao percebermos essa dimensão do discurso, é como se toda uma nova dimensão da realidade histórica se abrisse para o historiador em geral e para o historiador intelectual em particular. $\mathrm{O}$ avanço teórico no entendimento da linguagem trouxe desafios metodológicos e de redefinição do próprio campo da historiografia acadêmica. Falarei, muito rapidamente, de alguns deles, de maneira não exaustiva. Felizmente, já existe uma crescente bibliografia escrita por pesquisadores brasileiros que discutem essas consequências.

\section{Desnaturalização e ampliação da noção de contexto}

A velha discussão entre abordagens internalistas e externalistas no trato da história intelectual pode ser relativizada e levada a um novo momento. Como a linguagem é agora entendida enquanto estrutura e evento, Langue e Parole, o contexto ou a externalidade que mais deve nos interessar está também definido linguisticamente. Entender um texto como um enunciado significa recolocá-lo no interior da língua e da conversação, na qual ele pode ter feito sentido para seus ouvintes ou leitores. Assim, no lugar de simplesmente situar o texto no interior do estado da arte da história social e política, procurando entendê-lo como resposta a esses domínios, podemos agora também e principalmente confrontá-lo com um contexto linguístico historicamente controlável. O projeto de estudar os conceitos históricos, os vocabulários e as linguagens ganha então o sentido da montagem de contextos próprios para os fenômenos intelectuais. Não quero dizer com isso que estaremos desobrigados a tomar conhecimento dos avanços dos demais setores da historiografia, seja ela econômica, seja ela social ou política, mas que esses outros contextos não podem mais reivindicar centralidade na explicação desses fenômenos. Por outro lado, essas histórias não podem ser bem escritas sem incorporar os avanços na descrição desses contextos linguísticos. 
Não pode haver realidade social, ou de qualquer outra natureza, independente das dimensões linguísticas. Portanto, a dimensão social é também determinada pelas realidades linguísticas. Assim, estaríamos mais frente a uma circularidade do que de uma determinação de mão única. A velha oposição entre o prático e o discursivo, que parecia ser capaz de isolá-los como realidades distintas, não tem mais sustentação teórica suficiente.

\section{Descentramento da obra e do autor como bases de análise}

De modo complementar, já não faz sentido nos limitarmos às antigas unidades de análise da história intelectual, tão caras às abordagens internalistas - refiro-me especialmente às unidades de obra e autor. Embora sejam ainda relevantes, essas abordagens podem sofrer tanto pelo esgotamento e rotinização das agendas de pesquisa quanto pela naturalização ou congelamento dessas unidades. Sabemos as dificuldades de iniciar uma pesquisa razoavelmente original em torno exclusivamente de autores e obras clássicas. A excessiva especialização muitas vezes limita consideravelmente o impacto dessas pesquisas para fora de suas próprias subcomunidades acadêmicas. $\mathrm{O}$ enfraquecimento dessas antigas unidades abre espaço para a construção de novos objetos de pesquisa, como é o caso dos "vocabulários"; "conceitos históricos"; "linguagens" e "narrativas". Um traço comum a esses novos objetos de estudo é a necessidade de maior amplitude documental de um lado, e, por outro, a desconstrução das unidades autor e obra. Podemos assim analisar um grande clássico ou autor não preocupados com sua unidade interna, mas com a presença desses novos fenômenos cujo contexto é menos o autor e a obra e mais o próprio horizonte discursivo vigente em sua enunciação.

\section{Esgotamento da noção de influência}

A velha categoria da influência, cara à tradicional história das ideias, cede lugar para formas de transplantação, tradução e circularidade de uma mesma experiência histórica em diversos cenários nacionais, regionais e locais. A figura solar do autor/sujeito com sua intencionalidade é relativizada frente à nova concepção do texto enquanto acontecimento $\mathrm{e}$ pragmática, bem como pela ênfase nos contextos e jogos de linguagem que têm como território não a mente autoral, mas os veículos de circulação e espaços de sociabilidade (POCOCK, 2003, p. 23-62; SKINNER, 2006, p. 103-127). Da mesma forma que o sujeito-autor, 
também o sujeito-nação tem sua capacidade explicativa relativizada quando nos damos conta das múltiplas territorialidades relacionais concretamente produzidas em um determinado tempo/espaço. Não é possível falar de conceitos nacionais enquanto algo isolado das teias formadas na circulação entre o local, o regional e o global.

A leitura dos textos históricos deixa de ser apenas a busca de uma romântica empatia com o autor, ou ainda a coleta de informações não intencionais como matéria-prima da história social, das representações coletivas ou da crítica das ideologias. Como testemunho histórico efetivo de mundos da vida não mais inteiramente disponíveis, os textos podem nos oferecer um acesso privilegiado às formas pelas quais determinada sociedade experimentou, concebeu e prefigurou a realidade. Como demonstrou Reinhart Koselleck, a linguagem é sintoma e produtora de transformações sociais, portanto, mesmo que possamos articulá-la com as demais dimensões constitutivas do real, não podemos nos esquecer de seus movimentos autônomos, capazes de produzir novas e imprevistas configurações.

\section{Do interesse como explicação ao interesse como problema}

Contraparte das noções fortes de autor, influência e contexto, a crença de que se pode explicar as ideias de um texto pelo interesse de seus autores guiou boa parte da história intelectual. Remeter o texto ao seu contexto significava buscar as motivações e os interesses que teriam levado tal autor, consciente ou inconscientemente, a produzir o seu texto. Como as suas contrapartes, a noção de 'interesse' precisa ser desnaturalizada e problematizada, tornando-se ela mesma objeto de análise. Afinal, como chegamos a nos interessar pelo que nos interessa? Quais os modos de produção do interesse? Por que, em momentos históricos distintos e em diferentes sociedades, os interesses são constituídos de modo variado? Assim, não podemos mais pensar o interesse como uma "realidade social bruta", mas como construção histórica na qual a linguagem joga sempre um papel decisivo (BAKER, 1990, p. 5).

\section{O que são linguagens político-historiográficas?}

Muitas outras categorias precisariam ser reavaliadas a fim de produzirmos um vocabulário analítico e descritivo capaz de fazer jus a essa nova concepção de linguagem e história, no entanto, no lugar de continuar nessa direção, o que gostaria de propor neste artigo é o 
desenvolvimento dos contornos de uma modalidade de objeto para a história da historiografia que tenho chamado de "linguagens políticohistoriográficas". Partindo da definição já clássica de "linguagem política" presente na "Escola de Cambridge", tenho procurado isolar uma modalidade de linguagem política cuja função principal é produzir descrições e interpretações do tempo histórico. Acreditamos que com a centralidade crescente da escrita da história essa modalidade de "linguagem política" tornou-se mais importante, constituindo-se em um dos pilares da ideologização dessas linguagens; ou seja, da sua integração em visões de mundo.

O discurso político sempre teve de propor soluções para perguntas tais como: qual é a natureza do homem? Qual deve ser a melhor forma de governo? O que significa liberdade? Quais os limites do poder? Com a abertura dos tempos modernos, nenhuma dessas questões poderia ser respondida sem uma pré-compreensão do sentido da história, seja ela passada, seja presente ou futura. Assim, veremos uma politização crescente da agenda historiográfica, bem como uma historicização da agenda política. Muitos autores chamaram esse momento de historicismo, um tema clássico para a história das ideias. Acredito que podemos suspender essa categoria e estudar tais fenômenos a partir de objetos de análise mais precisos.

O fundamental em uma "linguagem político-historigráfica" é que nela encontramos reunidos tanto um conjunto de valores e modelos interpretativos para a vida política quanto uma concepção de história e escrita da história. A seguir, proponho um estudo de caso - para o mundo luso-brasileiro à época da Independência do Brasil - do que considero um dos melhores exemplos de "linguagem político-historiografica" vigente entre os séculos XVII e XIX em diversos contextos históricos no Ocidente, o tacitismo.

\section{Alguns significados de temas tacitistas entre 1800 e 1830}

O tacitismo teve suas primeiras formulações ${ }^{1}$ em 1572, quando Justus Lipsius ressaltou sua validade para o entendimento do comportamento político e, em 1581, quando Carolus Pachalius publicou o primeiro comentário político sobre a obra do historiador latino Tácito. ${ }^{2}$

Esta questão foi abordada com maior detalhamento em outro artigo (VARELLA \& VALDEI, 2009, passim).

2 Isso não que dizer que mesmo antes não possamos encontrar temas de leitura, especialmente da Germânia, que se agregariam ao tacitismo, como aponta KELLEY (1978, p. 416-417). 
O tacitismo surgiu nesse contexto e consolidou-se como forma de análise das obras taciteanas em 1590, caracterizando-se, assim, pela utilização da linguagem taciteana e dos escritos históricos de Tácito na explicação do comportamento político e, consequentemente, na arte de desvendar o que está sob as aparências. O objetivo principal do "tacitismo era fornecer indiretamente a análise da situação política contemporânea" (MOMIGLIANO, 2004, p. 157 e 183). A utilização das obras de Tácito gerou duas vertentes de interpretação distintas. A primeira delas foi construída através da Germânia, obra que trata dos costumes do povo germano e conta com trechos comparativos entre esses e os romanos (Idem, p. 157). Os alemães buscaram, na descrição de Tácito, que nunca foi à Germânia, a origem de sua liberdade e, mais que isso, a "reivindicação de independência e talvez de superioridade em relação às Romas imperial e papal” (Idem, p. 173).

As obras históricas, principalmente os Anais, serviram para revelar os segredos do império, ou seja, foram utilizadas como reveladoras do comportamento político e da ação governamental (Idem, p. 157). O relato da tirania imperial e de suas consequências feito nas Histórias e nos Anais foi utilizado de forma exemplar para entender o presente. ${ }^{3}$ Como argumenta Arnaldo Momigliano, "o verdadeiro objetivo de Tácito era desmascarar o governo imperial, enquanto fundado na corrupção, hipocrisia e crueldade" (Idem, p. 167). Nessa perspectiva, o recurso aos ensinamentos de Tácito foram entendidos de duas formas distintas. Algumas vezes ele era tido como o grande vilão que apoiava os déspotas e outras como o justiceiro que mostrava as tiranias imperiais e os perigos de um governo baseado no medo.

No mundo de língua portuguesa, podemos verificar um sensível deslocamento da avaliação da obra de Tácito, particularmente dos Anais. Até a primeira metade do século XVIII, vemos predominar a avaliação que possamos chamar de analógica, por enfatizar os elementos de estilo e composição, mas compatíveis com uma apreciação retórica, talvez fruto de um certo interdito ao "maquiavelismo" que muitos autores identificavam em sua obra. Ao revelar os segredos do poder os seus livros poderiam ser vistos como manuais de tirania. ${ }^{4}$ Sumariando as ambiguidades da recepção de Tácito na Península, escreve Isabel Almeida:

Para uma análise geral dos significados da obra historiográfica de Tácito, ver VARELLA (2008, passim).

4 Para a recepção do tacitismo na península ibérica no contexto de um "pragmatismo católico", ver Oliveira (2006, p. 106). 
Lembremos Saavedra Fajardo, que se pronunciou contra a divulgação indiscriminada de Tácito, reservando o nulla obstat para o acesso de público erudito; lembremos Antonio de Herrera, dividido entre a apologia e o ataque; lembremos como a Companhia de Jesus recuou no tocante à aceitação que concedera ao autor latino, e como a fulcral Ratio Studiorum de 1598, ostensivamente ciceroniana, reviu o corpus paradigmático preconizado doze anos atrás, silenciando Cornélio Tácito. (ALMEIDA, 2009, p. 64).

A exclusão de tácito da Ratio jesuítica ajuda a explicar o crescente interesse por este autor a partir das reformas pombalinas. O elogio da concisão retórica era o mesmo, mas outro Tácito e outra retórica começariam a emergir. Um sinal tardio dessa renovação são as diversas traduções, como o renovado e afamado Manual de Retórica e Belas Letras do escocês Hugh Blair, com uma grande seção dedicada ao modo de se escrever e compreender a história. Lamentando que muitos dos historiadores antigos haviam colocado mais energia na beleza e estilo da narrativa do que na exposição das causas das grandes revoluções, Blair aponta Tucidides, Políbio e Tácito como as três grandes exceções:

Tucídides es grave, inteligente, y juicioso; y siempre cuidadoso de dar una idea exacta de las operaciones que refiere, y de manifestar las ventajas ó perjuicios de cualquier plan que se proponía, y de cualquier medida que se tomaba. Polibio se distingue por sus grandes conocimientos en política, su penetración en los sistemas de mayor interés, y su profunda y clara instrucción en los negocios militares. Tácito sobresale por el grande conocimiento del corazon humano: es sensible y fino en sumo grado: $y$ da mucha instruccion en las materias políticas, pero aun mas todavía sobre la naturaleza humana. (BLAIR, 1804, p. 229. Grifo do autor).

Para os homens que vivenciaram a crise do que chamavam de "Antigo Sistema Colonial" no mundo luso-brasileiro, as referências a Tácito eram razoavelmente comuns e podem ser organizadas em alguns temas mais recorrentes que juntos formam algo que podemos caracterizar como uma linguagem "tacitista". Dentre esses temas, destacaremos alguns, a saber: a) A descoberta da tirania; b) Os Arcana Imperii; c) A relação entre censura e decadência político-intelectual; d) Os fundamentos do constitucionalismo entre os Germanos; e) $\mathrm{O}$ projeto de uma escrita da história "sine ira et studio" e f) A escrita da história como ação política indireta. Faremos, a seguir, uma breve descrição de cada um desses temas tacitistas em uso nos autores lusobrasileiros no começo do século XIX. 


\section{A descoberta da tirania e a natureza humana}

Se nos manuais de retórica mais tradicionais Tácito é sempre elogiado pela concisão da expressão e capacidade de sintetizar grandes quadros em frases lapidares ${ }^{5}$, a tradição tacitista de comentário político privilegiou o Tácito leitor da hipocrisia, cronista do poder desmesurado dos imperadores, do isolamento e da manipulação do poder por libertos. O tema da escravidão surge aqui como uma descrição do estado do povo romano sob o poder dos maus imperadores.

O juízo que os leitores faziam sobre o significado das críticas de Tácito aos Imperadores romanos era variado. Para alguns, como o Visconde de Cairu, Tácito teria mostrado no principado de Tibério como era possível hamonizar liberdade e autoridade, um dos grandes desafios teóricos enfrentados nos limites do chamado republicanismo cívico. Assim, em 1825, Cairu usaria esse símile para atribuir a Dom Pedro I o papel de novo Tibério, citando uma famosa passagem da Vida de Agrícola $^{6}$ como epígrafe ao seu livro:

Primo statim beatissimi Imperii ortu res olim dissociabiles miscuit, Principatum ac Libertatem...

Nunc redit animus: non pigebit rudi et incondita voce memoriam praesentium temporum composuisse (Lisboa, 1825-1830: v. I, p. 1).

[tradução: Outrora ele misturou, desde o começo do opulento Império que inicia, coisas até então incompatíveis: Principado e Liberdade...

Agora o ânimo volta: ele não terá arrependimento de ter reunido a memória dos tempos presentes com uma voz rude e bárbara]. ${ }^{7}$

O Tácito leitor da natureza humana, capaz de revelar o caráter de um personagem pelos pequenos gestos, será cada vez mais evocado por uma opinião pública que já não aceitava a ideia de que a política era uma prerrogativa real. Chamado a ajuizar sobre o comportamento político

5 Também José Silva Lisboa, o Visconde de Cairu, faria coro a essa vetusta tradição ao afirmar "Não sou Tácito, que (segundo Montesquieu diz) abreviava tudo, porque via tudo [...]" (LISBOA, 1825-1830, p. 22).

6 A mesma passagem já havia sido utilizada, com a mesma significação, para caracterizar uma das administrações do distrito diamantino em outra obra histórica de Cairu. (LISBOA, 1818, p. 7).

7 Agradeço a Flávia F. Varella pela tradução desta passagem latina. Para os interessados em uma análise geral da historiografia de Tácito, ver Varella (2008: passim). Em artigo, ainda inédito, sob o título "Cairu e a emergência da consciência historiográfica no Brasil (1808-1830)", pude analisar mais detidamente a montagem a que Cairu submete a citação original de Tácito, muito diferente da que apresenta. 
dos homens públicos, esse auditório precisava adquirir a capacidade de avaliar o que estava por trás das aparências ou oculto pelos segredos do Estado. O que no século XVII poderia ser visto como um manual para o uso do príncipe era agora "democratizado" como uma "tecnologia" social necessária para o homem comum chamado à vida pública. A experiência das Cortes e Assembleias e o debate pela imprensa foram os ambientes privilegiados dessas experiências de anatomia moral.

\section{Os Arcana Imperii}

Inspirado um uma célebre passagem em que Tácito reflete sobre as dificuldades de escrever a história do principado, uma vez que os assuntos importantes não eram mais discutidos no espaço público do Senado, mas no interior da domus imperial, muitos leitores de Tácito vão associá-lo ao projeto de uma escrita da história contemporânea que pudesse revelar, aos olhos da opinião pública, os "segredos do Estado", as intrigas de gabinete, os malfeitos dos funcionários que procuravam ocultar suas ações. Esse tema será comum no periodismo da época, que não poucas vezes vai assumir a função de uma espécie de história do tempo presente, estabelecendo os fatos como os anais na antiga Roma republicana que idealizavam em uma leitura muito pragmática de Tácito.

Os Ingleses lamentam a sua perda de caráter; aos portugueses pertence deplorar as más consequências daquela desventurada convenção, pelo que toca a Portugal; e a mim, que escrevo em Inglaterra as memórias do tempo, convêm mostrar o modo porque nisto se portaram as pessoas públicas aqui empregadas pela Nação Portuguesa [...] (COSTA, 1808, p. 318. Grifo do autor.).

Alguns autores não se furtavam a inverter o significado da fórmula tacitista, como é o caso do bem mais conservador Visconde de Cairu, que ao tentar justificar a necessidade do historiador contemporâneo de preservar os interesses do Estado escreveu: "Ainda que soubesse dos segredos do Gabinete no curso dos Sucessos (o que está fora do meu alcance) devia conformar-me à regra de Tacito - ne revelaret arcana imperri." (LISBOA, 1824-1839, v. I, p. V).

\section{A relação entre censura e decadência político-intelectual}

Hipólito José da Costa encontrará na tradição tacitista, como muitos de seus contemporâneos - a exemplo de seu rival José Liberato Freire de Carvalho -, os elementos da montagem de uma metanarrativa 
para a história de Portugal, que estabelecia uma relação de causa e efeito entre despotismo religioso e decadência das letras e ciências. Em suas palavras:

[...] os Eclesiásticos para tornar a chegar ao estado de pisar impunemente o Soberano, como de antes fizeram, precisam que o reino torne atrás ao estado de ignorância, em que então se achava, o que só pode conseguir-se, pondo entraves à propagação das ciências, debaixo do pretexto de censuras, e outros motivos especiosos, que nunca faltaram aos homens mal intencionados para fazer monopólio das ciências, e deixar a nação no estado de ignorância, que foi tantas vezes em Portugal a única causa dos desgostos, que os Papas causaram aos Soberanos. (COSTA, 1809, p. 532).

A defesa da liberdade de expressão e do favorecimento de uma República das Letras autônoma encontrava em diversos temas da obra taciteana elemento de reforço. A defesa das Letras era a defesa da opinião pública como única esfera capaz de impedir que grupos privados, como os libertos em Roma e os Jesuítas em Portugal, utilizassem do poder do rei para alcançar seus objetivos particulares. No artigo Reflexões sobre o comportamento dos Portugueses, de 1808, Hipólito já reflete sobre o tema:

[...] o Soberano terá vassalos fiéis, esforçados, e tão prontos a derramar seu sangue em defesa do Monarca, como sempre se observou nos antigos tempos; a Nação é a mesma, mas para obrar do mesmo modo conservem-lhe seus foros antigos: exemplo a Espanha; outra vez repito, exemplo a Espanha, obrando como Nação, livre das intrigas ocultas de um Gabinete, onde com a capa do bem público se engana o Soberano, e se guia a sua ruína. A discussão dos negócios públicos nas Cortes foi sempre em Portugal o único meio de poderem os Reis saber a verdade, que eles nunca podem esperar de ouvir da boca de cortesãos corrompidos, cujo interesse é agradar ao Soberano seja ou não seja á custa da verdade. (COSTA, 1808A, p. 142-3. Grifo do autor).

O absolutismo do poder real não seria incompatível com a existência de Cortes e Parlamentos, a sua degeneração em despotismo aconteceria quando os aduladores e os ambiciosos insuflariam no monarca ideia de um poder ilimitado. Os reis portugueses estariam mais vulneráveis a esses procedimentos pelo fato de, diferente da Inglaterra, onde o rei teria principiado com poder absoluto e somente depois foi sendo paulatinamente limitado por leis e instituições, o monarca luso "[...] em princípio dependia dos povos em muitos casos, mas desta dependência 
gradualmente se isentou" (COSTA, 1810, p. 83). A adulação encontra terreno quando o povo perde sua unidade de propósito e divide-se em múltiplos partidos. Esse elemento será recordado por ocasião da polêmica com o Correio do Orinoco a propósito da revolução de Pernambuco: "Dos mesmos Romanos, diz Tácito (Hist. 1.1) que vistas às dissensões do povo, não tinha a pátria, no tempo de Augusto, outro remédio se não escolher o Governo de um só homem" (COSTA, 1819, p. 269).

Outro personagem com posições políticas um tanto distintas de Hipólito, José da Silva Lisboa, também recorreria ao repertório tacitista para criticar os efeitos nefastos da censura prévia sobre a civilização dos povos e a natureza dos governos: "O político historiador Tácito bem notou a inutilidade de tal expediente, ainda nos despóticos reinados dos Imperadores Romanos. O risco da proibição forçava procurá-los e escondê-los; depois a licença de os possuir fazia que caíssem no esquecimento" (LISBOA, 1824-1830, v. 2, p. 93-4).

\section{Os fundamentos do constitucionalismo entre os Germanos}

A partir das críticas aos revolucionários franceses que tentariam, a partir de abstrações, reformar a sociedade, reforçou-se em toda a Europa a busca das origens históricas dos sistemas políticos. No caso luso-brasileiro não foi diferente, os críticos da monarquia absolutista, fundados em teorias já disponíveis no reformismo ilustrado, buscavam demonstrar que o modelo de um rei centralizador que atribuíam a Pombal era um desvio da evolução histórica de Portugal. Desde moderados que procuravam distinguir entre absolutismo e despotismo, até liberais mais avançados, todos recorriam a uma famosa passagem da Germânia para "provar" que os primeiros portugueses reuniam-se em corte e o povo dividia as responsabilidades de mando com o rei.

Hipólito José da Costa procurou escrever uma História filosófica ou hipotética da liberdade em Portugal, que pressupunha que a antiga liberdade dos lusitanos perdeu-se devido à introdução da Inquisição, a falta de patriotismo nos indivíduos que preferiam "um repouso de escravos aos incômodos e perigos necessários para se obter uma liberdade bem entendida" (COSTA, 1809, p. 117). Para Hipólito, como no caso britânico, foram os povos do Norte, entendam-se os germanos, que fundaram a monarquia portuguesa após invadirem o Império Romano (Idem, p. 119).

Na escrita dessa história da sociedade civil em Portugal, o historiador não poderia contar com documentos autênticos e "positivos", por isso deveria recorrer ao método hipotético, utilizando-se da analogia e da 
comparação com os costumes desses povos fundadores “[...] que havendo passado o Reno se apoderaram de toda a Europa". A todo o momento uma visão idílica opõe os jovens e livres germanos aos amolecidos e despóticos romanos, como na seguinte passagem, comparando a instituição da escravidão: "Os escravos entre os germanos gozavam de mais suave condição do que entre os romanos, pelo testemunho do mesmo Tácito; não podendo os senhores exercitar para com eles o direito de vida e de morte, que tinham os Romanos." (COSTA, 1819, p. 153).

Nessa história hipotética fundada na comparação com os Povos do Norte, Hipólito encontrou argumentos tanto para condenar o despotismo, quanto para defender a natureza absoluta do poder do rei em Portugal. Como muitos de sua geração, as causas da decadência estavam ligadas ao enfraquecimento do poder do rei em favorecimento de nobres amolecidos ou religiosos fanáticos e gananciosos. No entanto, esse poder absoluto não era incompatível com a existência e funcionamento de Cortes, como ele acredita ter descoberto lendo a Germânia, citada como fonte de autoridade:

A primeira ideia de Cortes e de Parlamento inquestionavelmente se deduz das Nações do Norte da Europa, que se estabelecerão em Portugal e em Inglaterra. Em nenhuma daquelas nações costumavam os povos entregar ao seu primeiro magistrado, chefe, ou Soberano, todo o poder de governar, sem reserva ou restrição. Era costume de todos estes povos congregarem-se em assembleias, onde se discutiam, e decidiam os negócios de maior importância para a nação; não se confiando jamais, nestes casos, de um só homem, o qual pode suceder, que obre contra o interesse dos povos e venha o mal, a ser ao depois irremediável. (COSTA, 1809, p. 623. Grifo do autor). ${ }^{8}$

Os exemplos desse uso "constitucional” da obra de Tácito poderiam ser multiplicados e voltaremos ao tema na seção sobre a tradução dos Anais. Por ora, fiquemos com mais um exemplo, tirado das atas do debate parlamentar acerca da constituição em Portugal em 1821:

Em quanto à segunda, convenho em que as nossas leis fundamentais não falam em Cortes; mas devo observar que o nosso direito público não foi fundido de um só jacto, nem derivado de uma só fonte. Do direito consuetudinário nos vieram estas grandes assembleias da

8 A citação é a seguinte: "De minoribus rebus príncipes consultant, de majoribus amnes." Tacit. De morib. Germ. C. 11. 
nação chamadas Cortes; e se acreditarmos um ilustre autor português, já estas assembleias eram conhecidas dos antigos lusitanos, antes da invasão, dos povos do norte; a quem outro as atribui, fiado no testemunho de Tácito, que diz - de minoribus rebus principes consultant; de majoribus omites. (CARMO, 1878, p. 198)

\section{O projeto de uma história 'sine ira et studio'}

A necessidade de imparcialidade e isenção por parte do historiador é um tema tão antigo quanto a própria historiografia; ele apresenta desafios que são, ao mesmo tempo, de ordem ético-políticos e epistemológicos. Como um dos primeiros a revelar a força do poder e dos interesses sobre a escrita da história, Tácito será evocado por um contexto de vida política onde a cidadania disputava com o Estado e entre si projetos para o futuro. Frente à luta de interesses, que não poderiam ainda ser admitidos enquanto tal, era preciso reforçar o valor ético e epistemológico de suas próprias posições. Assim, ao evocar a máxima taciteana - sine ira et Studio - buscavam autoridade discursiva em um contexto de crise das formas tradicionais de autoridade:

[...] o meu intento é informar os portugueses presentes, e vindouros, do modo porque os servem os homens públicos, que eles empregam, conservando porém a minha costumada imparcialidade. 'Mihi nec Galba, nec Otto, nec Vitelius /Injuria aut benefio cogniti.' Tácito, Histórias. (COSTA, 1808, p. 319). ${ }^{9}$

$\mathrm{Na}$ medida em que o passado já não lançava mais luz sobre o futuro, a escrita da história contemporânea adquiria maior centralidade, mas com ela as conhecidas dificuldades de produzir autoridade para um relato escrito no calor da hora.

\section{A escrita da história como memória e vingança contra a tirania}

Escrevendo sobre imperadores já mortos, Tácito criou a noção de uma história vingadora, juíza da posteridade, mas o fazia em detrimento da possibilidade de escrever a história de seu próprio tempo, ainda marcado pelo poder do Imperador. No contexto da crise da Independência, a consciência do caráter transitório do tempo reforçava a necessidade de registrar para o futuro os "anais", a partir do qual os homens e o tempo

9 O trecho citado em latim pode ser assim traduzido: "Nem Galba, nem Oton ou Vitélio fizeram-me injuria ou beneficio". 
poderiam ser julgados. Vencidos e vencedores procuravam garantir o fatal juízo da posteridade, procurando pré-determinar o significado da história que estavam fazendo e sofrendo. Frente aos limites do interesse, multiplicavam-se argumentos de distanciamento: ser estrangeiro, ser capaz de penetrar no significado filosófico dos eventos, ser patriota e não possuir interesses privados, dentre outros. Na seção seguinte, veremos como esse tema é um dos argumentos centrais que orientou à tarefa de tradução dos Anais.

\section{José Liberato Freire de Carvalho: o primeiro tradutor dos Anais}

A primeira tradução completa dos Anais para a Língua Portuguesa a ser publicada devemos a José Liberato Freire de Carvalho, que imprimiu, entre 1820 e 1821, os dois primeiros livros dos Anais no periódico $O$ Campeão Português. Em 1830, sairia pelas mãos do editor francês Aillaud a tradução completa. A história dessa tradução, produzida entre 1809 e 1829 , e os motivos alegados por seu tradutor para empreender a tarefa de verter a maior obra de Tácito para a Língua Portuguesa, oferecem-nos indícios de como a experiência daqueles anos de crise orientou e era, por sua vez, orientada pela releitura de alguns temas centrais da linguagem tacitista.

$\mathrm{Na}$ "Advertência" que antecede a tradução na sua edição de 1820 , Freire de Carvalho afirmaria o que seria uma espécie de mantra para muitos de sua geração, a admiração por Tácito como uma espécie de guia na luta contra os tiranos e seus governos:

Nestes dois anos de prisão constante foi, pois, começada e acabada

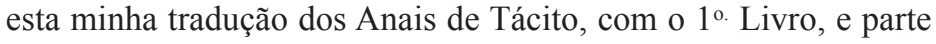
do $2^{\circ}$ das Histórias do mesmo autor. Assim parece justo que uma obra, feita originalmente para desmascarar a tirania, e traduzida por ocasião de um ato atroz da mesma tirania, não esteja por mais tempo privada da luz da Imprensa Portuguesa [...]. (CARVALHO, 1820 , p. 5. Grifo do autor).

Em diversas outras ocasiões, o tradutor fez questão de ligar os Anais à sua própria trajetória de vida, marcada, segundo ele, pela perseguição injusta e pela luta contra a opressão. Nascido em Coimbra, em 1772, Freire de Carvalho tornou-se cônego da regra de Santo Agostinho, junto à qual estudou filosofia e teologia, matérias que logo depois viria a lecionar no mosteiro de São Vicente de Fora em Lisboa, por volta de 1800, aos quinze anos (SILVA, 1859, p. 418-421; Carvalho, 1855, p. 411). 
Em suas "Memórias", publicadas já no final da vida em 1855, o tradutor oferece o relato mais detalhado de sua formação (Carvalho, 1885, passim). O significado dos estudos de filosofia e teologia - e talvez de todo o rumo de sua trajetória individual - seria transformado pela erupção do evento revolucionário na França, sobre o qual deixou o seguinte depoimento:

Era no ano de 1789 que começaram estes meus estudos, em que também começou a Revolução Francesa, e deles e dos extraordinários acontecimentos que aquela revolução foi produzindo, também na minha cabeça se operou uma revolução completa. Com sumo desejo de ler tudo o que se ia passando, li quanto pude haver à mão; e com esta leitura se entrou a desenvolver em mim um ódio profundo a tudo o que eram abusos, excessos de poder, absolutismo, tirania..." (CARVALHO, 1855, p. 410. Grifo do autor). ${ }^{10}$

A origem principal da linguagem para dar vazão a esse ódio à tirania, senão uma das fontes desse mesmo ódio, foi, para Carvalho, a obra de Tácito, como veremos adiante. É no período que leciona em Lisboa que efetivamente entrou na precária e perigosa vida política portuguesa de então. Afirma ter lido "[...] quanto bom e mal se tinha escrito em história, política, filosofia, e ciências morais no século passado, assim como o que se ia escrevendo no século que principiava [...]" (Idem, p. 411). Essas leituras logo chamariam a atenção das autoridades, sendo obrigado a deixar a cidade em 1805 para um primeiro exílio, retornando apenas em 1807, durante a "[...] entrada dos franceses, e fugida d'El-Rei D. João VI para o Brasil" (Idem, p. 411-2). É no Portugal disputado pelas tropas francesas e inglesas que vivenciou pela primeira vez a experiência da tirania, tornando-se ele próprio prisioneiro em Coimbra no ano de 1811. Foram nesses dois anos em que esteve preso que afirma ter concluído sua tradução dos Anais: "[...] com que passei toleravelmente meus dias, expondo à luz em português, língua em que ainda não tinham aparecido, os crimes e os castigos desses monstros humanos, que enxovalharam Roma, a rainha do mundo!" (Idem, p. 112. Grifo do autor).

A ideia da tradução the teria surgido quando, com a derrota das tropas francesas em 1809, teve de deixar Lisboa em direção à Coimbra, acusado de "francês" por seu envolvimento com a maçonaria. Com um amigo de passagem por Coimbra, José Ferreira de Moura, teria

${ }^{10}$ É preciso observar que esse julgamento claro e preciso do significado da Revolução Francesa era possível em 1854, quando tomou a decisão de organizar as suas memórias. 
combinado iniciar uma correspondência com o envio mútuo de traduções dos livros dos Anais:

Concordamos nesta correspondência, e d'aqui nasceu ter eu já o manuscrito de que há pouco falei. [...] Tive sempre uma grande paixão pelas obras de Tácito, porque nelas achava estampados os meus próprios sentimentos. Fui sempre, como ainda sou, inimigo irreconciliável de tudo o que é tirania, absolutismo, e abuso de poder; e com este caráter que recebi da natureza, e pelo muito que tenho sofrido pelos abusos desse mesmo poder, me abalancei a traduzir todos os Anais [...] com este trabalho satisfiz o meu espirito, consolando-me de pôr em português os crimes dos tiranos, que do coração aborreço. (CARVALHO, 1855, 71-2. Grifo do autor).

Em outra passagem das "Memórias", ele nos dá pistas sobre a edição que utilizou em sua tradução. Era o ano de 1810 e junto com parte de sua família haviam sido aprisionados pelas forças do Marechal Massena, comandante das tropas da nova investida francesa no território português. Ao atravessar a vau o Mondego, relata como teria guardado em suas botas "[...] uma pequena preciosidade, que, ao menos julgava como tal, e esta preciosidade (não se riam os meus leitores) era um pequeno livro latino do formato 24 , que continha todas as obras de Tácito, e da edição de Amsterdam do ano 1734, ${ }^{11}$ livrinho, que ainda hoje conservo" (CARVALHO, 1855, p. 71). Junto ao "livrinho" ia o manuscrito com a tradução do primeiro livro dos Anais, trabalho que completaria a seguir durante o período em que ficaria detido em Coimbra por ordem do novo governo constituído pelos ingleses, primeiro na cadeia da Universidade, depois no Convento de Santa Cruz.

Durante o deslocamento com as tropas francesas, a valiosa bota teria extraviado, perdendo o autor as esperanças de reavê-la, até que da casa de seus primos lhe enviaram um criado ao Convento, informando-lhe que lhe a haviam recuperado junto com o livro de Tácito e os referidos manuscritos. Decide então ocupar seu tempo no cárcere e continuar a sua tradução, pedindo a um amigo que lhe enviasse subsídios literários para empreender a tarefa:

\footnotetext{
${ }^{11}$ Provavelmente trata-se da seguinte edição: TACITUS. C. Cornelii Taciti opera quae extant omnia, ad fidem optimorum codicum manuscriptorum accuratissime castigata. Amsterdam, Apud Janssonio Waesbergios, 1734. Agradeço a Fábio Faversani pela ajuda decisiva na identificação do título e o entusiasmo com que sempre nos orienta nos assuntos taciteanos.
} 
[...] mandou logo uma bela edição de Brotier $^{12}$ com muitos comentários, notas e os suplementos, que fez aos livros que se perderam de Tácito, e com ele outra muito ilustrada edição alemã de 1801, feita por Oberlino ${ }^{13}$ creio que conjuntamente me mandou também a tradução espanhola do nosso português Soeiro ${ }^{14}$, da qual nada me aproveitei (CARVALHO, 1855, p. 115).

Em meados de 1813, teria terminado a tarefa da tradução. Nesse mesmo ano, após receber ordem de se transferir para uma prisão mais isolada no interior, decide, com o apoio de amigos do Porto, fugir para a Inglaterra. Em Londres, a exemplo de vários exilados portugueses, empregou-se na atividade jornalística, colaborando com o "Investigador Português” até 1819. De início, dedicado à luta geral contra a ocupação francesa e à expansão napoleônica, com o fim do conflito, o jornal passou a ser um dos defensores da causa portuguesa contra o que chamava de "injustiças do governo do Brasil" (Idem, p. 414). Nesse período, defende o caráter "constitucional" da monarquia portuguesa, retornando, segundo ele, às memórias do tempo para demonstrar aos povos do Brasil e de Portugal os rumos que deveriam garantir sua justa união. Esse mesmo ponto será mais detidamente desenvolvido no Ensaio histórico-político sobre a constituição e governo do reino de Portugal, publicado em 1830. Como era comum na época, o Tácito autor da "Germânia" era evocado como fonte de autoridade sobre as origens hipotéticas do espírito constitucional, argumentava-se no interior de uma narrativa que atribuía a Pombal o auge da usurpação do poder do povo em benefício do despotismo real, devendo-se então regenerar o equilíbrio histórico entres os poderes:

As formas constitucionais, ou as Cortes em Portugal, têm sido em todos os tempos conhecidos a cousa mais sagrada e importante que politicamente temos possuído; e delas sempre dependeram essencialmente, assim como ainda hoje dependem, as nossas liberdades. É uma instituição mui sagrada, porque sem haver sido sancionada na sua origem por lei alguma escrita, de que

${ }^{12}$ Gabriel Brotier (1723-1789), influente editor e comentador moderno das obras de Tácito em Latim. Certamente uma das fontes principais das abundantes notas que Carvalho insere em sua tradução.

13 Jérémie-Jacques Oberlin (1735-1806), outro editor e comentador das obras de Tácito em Latim. Sua edição de 1801 reimprime o célebre comentário de Justus Lipsius.

${ }^{14}$ Manoel Soeiro, cônsul português em Anvers, traduziu, no século XVII, os Anais para o espanhol, com edições em 1613 (Anvers) e 1614 (Madrid). Segundo Agostinho de Macedo, trata-se de Manoel Fernandes de Villa Real, judeu português refugiado na Holanda (MACEDO, 1901, p. 100). 
as histórias façam menção, sempre gozou do caráter de uma certa lei natural, que sem necessitar escrever-se com caracteres humanos, passa de geração em geração gravada na memória e no coração dos homens. Assim a instituição de nossas Cortes ou de uma representação nacional, se pode mui propriamente denominar uma lei da terra, fundada em imemorial e antiquíssimo costume, mantido entre as ruínas do império Romano por todas as nações do Norte que vieram fundar novos reinos e impérios na Europa, e chegaram até a extremidade dela, o nosso Portugal. Tácito, falando dos costumes dos Germanos, diz no capítulo XI: 'Os negócios pouco importantes são regulados pelos chefes; os mais importantes pela nação' (CARVALHO, 1830, p. 1-2. Grifo do autor).

Foi em 1819, no contexto da radicalização da luta pelo retorno de Dom João VI para Portugal e da agenda constitucionalista, que Freire de Carvalho deixou o Investigador Português, que considerava muito tímido, e criou o seu Campeão Português, o amigo do Rei e do Povo, também editado em Londres (CARVALHO, 1855, p. 417). Ao final desse mesmo ano, o jornal foi proibido de circular no Brasil e em Portugal. Radicalizava-se a conjuntura que culminaria nos acontecimentos de 1820 e 1822. Criado para defender o retorno de Dom João e o estabelecimento das Cortes, o jornal foi descontinuado em agosto de 1821, mas não sem antes ver publicado em suas páginas os dois primeiros livros dos Anais traduzidos nas difíceis condições que Freire de Carvalho não se cansou de repetir sempre que pode, afinal, era na imagem de um Tácito inimigo da tirania que buscava dar sentido e coerência à sua trajetória de vida. Nesse mesmo ano voltaria a Portugal "para assistir os progressos da pátria”. Atuou intensamente na vida política até a sua morte, em 1855, não sem um novo exílio londrino em 1828, por conta dos conflitos sucessórios entre Dom Miguel e Dom Pedro.

Foi desse novo exílio londrino em 1830 que, a pedido do editor e amigo Aillaud, publicaria finalmente a tradução completa dos Anais em Paris e no Rio de Janeiro. Nas "Memórias" esclarece que somente em Londres pode retornar ao manuscrito de 1813 e compará-lo com os "[...] dois tradutores franceses Dureau de la Malle" e Gallon de la Bastide $^{16}$, porque, devo confessar, que o meu primeiro trabalho [em 18111813] só se concluiu à vista dos comentadores latinos, que foram com

15 Trata-se de Jean-Baptiste Dureau de La Malle (1742-1807), que em 1793 publicou uma influente tradução das obras de Tácito para o francês, reeditada em 1808 e 1816.

${ }^{16}$ Outro célebre tradutor da obras completas de Tácito para o francês, editada em três volumes em 1812. 
especialidade Brotier e Oberlino" (CARVALHO, 1855, p. 320). Afirma ter ainda nessa ocasião cotejado a sua tradução com uma espanhola, "cujo nome" não recordava, além de alguma tradução francesa. O fato é que Aillaud lhe pagaria a pequena fortuna de mil francos pela tradução, o que é um indicativo do bom negócio que deveria ser editar Tácito naquele tempo. ${ }^{17}$

O historiador romano sempre seria evocado por Carvalho como uma espécie de atestado de pureza de suas convicções políticas. Em 1834, quando participou da decisão parlamentar que expulsou Dom Miguel de Portugal, ainda lembraria seu trabalho como tradutor dos Anais, dizendo que se orgulhava de ter tomado parte nas negociações que levaram à queda de Dom Miguel, pois "[...] sempre detestei os tiranos; e uma das ocupações mais agradáveis que tive na minha vida foi a de traduzir os Anais de Tácito, o meu livro mimoso" (Idem, p. 375). Continuava a sua descrição oferecendo uma das análises mais explícitas do que os leitores de sua época buscavam na obra do autor da Germânia: "Como me consolava quando via o autor ir dissecando com o seu afiado escalpelo fibra a fibra o coração corrupto dos monstros, que tinham governado Roma! Parecia-me estar ainda vendo seus cadáveres expostos à execração do mundo!" (Idem, p. 376).

No prólogo à edição de 1830 , é ainda mais preciso, definindo Tácito como o mais profundo "anatomista moral", o mais "analítico indagador do coração humano". Além de simplesmente narrar os fatos, o autor romano saberia mergulhar "[...] ao interior da consciência dos tiranos, que ele tão habilmente sempre [soube] desenhar"; não deixaria escapar qualquer circunstância, sentimento ou paixão:

Debaixo dos pincéis de Tácito vemos, como diante de um espelho, a alma refolhada e tenebrosa de Tibério; a estúpida insignificância de Claudio; a bárbara dissimulação de Nero no meio de lodos os seus atrozes delírios; e vemos em fim os crimes e as dissoluções da ambiciosa Agripina para dar um trono usurpado a um filho digno de tal mãe (CARVALHO, 1830B, p. 1).

No interior da linguagem tacitista, Freire de Carvalho enredava os eventos de sua vida conturbada, da história que fazia e sofria com o próprio texto dos Anais. Se for verdade que ao traduzir um texto o autor

\footnotetext{
${ }^{17}$ Até onde sei a tradução de Carvalho continua sendo a única completa dos Anais em português, sendo, até pouco tempo seguidamente reeditada na coleção Clássicos Jackson, omitindo-se a "Advertência" que o tradutor tão zelosamente havia anteposto ao seu texto e que, de certa forma, é essencial para se compreender o "espírito" de sua tradução.
} 
lhe acrescenta os horizontes de suas experiências, não é menos certo que o texto e a linguagem no interior da qual ele pode ser lido ajudam a prefigurar os quadros no interior dos quais a experiência pode ganhar forma. A tradução, fruto dessa fusão de horizontes, torna-se então um documento histórico privilegiado desse encontro de horizontes. Para os leitores de Tácito do começo do século XIX, a ausência de uma consciência histórica hipertrofiada dava-lhes ainda mais liberdade para apropriarem-se do legado literário do mundo Antigo. Compreender essas formas de apropriação, os significados que esses textos poderiam ter para seus leitores, e que já não têm para nós, é uma das tarefas centrais de uma história intelectual renovada.

\section{Referências}

ARAUJO, Valdei Lopes de. A experiência do tempo: conceitos e narrativas na formação nacional brasileira (1813-1845). São Paulo: Hucitec, 2008a.

. História dos conceitos: problemas e desafios para uma releitura da modernidade ibérica. Almanack Braziliense, v. 7, p. 47-55, 2008b. Disponível em: <www.almanack. usp.br/>.

ALMEIDA, Isabel. As subtis linhas da humana dissimulação. Península, Revista de Estudos Ibéricos, n. 6, p. 61-68, 2009.

BAKER, Keith Michael. Inventing the French Revolution. Cambridge: CUP, 1990.

BLAIR, Hugh. Lecciones sobre la retorica y las bellas letras. 2. ed. Madrid: Imprenta Real, 1804. Tomo III.

CARMO, Bento Pereira do. Discurso proferido durante a segunda sessão de discussão do articulado do Preâmbulo da Constituição de 1821. In: AZEVEDO, Luís Manuel Prado de. Discursos Parlamentares de Oradores Portugueses. Porto: Escritório da Empresa, 1878. v. I, p. 191-200.

CARVAlHO, José Liberato Freire de. Os Anais de Cornélio Tácito. Trasladados em língua portuguesa, agora por... primeira vez impressos e publicados O.D.C. Aos subscritores do Campeão Português. Londres: Impresso por L. Thompson, 1820 .

CARVALHO, José Liberato Freire de. Ensaio histórico-politico sobre a constituição e governo do reino de Portugal. Lisboa: Paris: Casa de Hector Bossange, 1830.

CARVALHO, José Liberato Freire de (tradutor). Os Anais de Cornélio Tácito. Traduzidos em linguagem portuguesa e oferecidos à sua pátria e amigos. Paris: em casa de J. P. Aillaud Editor; Rio de Janeiro: em casa de Souza Laemmmert e Cia., 1830b.

COSTA, Hipólito José da. Paralelo da Constituição Portuguesa com a Inglesa. In: . Correio Braziliense, São Paulo: Imprensa Oficial do Estado: Brasília, DF:

Correio Braziliense, 2002 [1809]. v. III, p. 175-182.

Paralelo da Constituição Portuguesa com a Inglesa. Correio Braziliense, São Paulo: Imprensa Oficial do Estado: Brasília, DF: Correio Braziliense, 2002 [1810]. v. IV, n. 6, p. 83 . 
COSTA, Hipólito José da. Reflexões sobre o comportamento dos Portugueses. Correio Braziliense, São Paulo: Imprensa Oficial do Estado: Brasília, DF: Correio Braziliense, 2002 [1808a]. v. I, p. 142-143.

. Portugal. In: Correio Braziliense, ou, Armazém Literário, São Paulo: Imprensa Oficial do Estado: Brasília, DF: Correio Braziliense, 2002 [1808b]. v. I, p. 318-324.

Justificação do Correio Braziliense, contra o Correio de Orinoco. Correio Braziliense, São Paulo: Imprensa Oficial do Estado: Brasília, DF: Correio Braziliense, 2002 [1819]. v. 23, p. 269.

DINIZ, Bruno. Cairu e o primeiro esboço de uma história geral do Brasil independente. História da Historiografia, n. 2, p. 260-266, mar. 2009.

KELLEY, Donald R. Review of 'Tacitus in Renaissance Political Thought by Kenneth C. Schellhase. Speculum, v. 53, n. 2, p. 416-417, Apr. 1978.

LISBOA, José da Silva. História dos principais sucessos políticos do Império do Brasil. Rio de Janeiro: Tipografia Nacional, 1825-1830. 4 v.

. Memórias dos Principais Benefícios Políticos de el Rei Nosso Selnho Dom

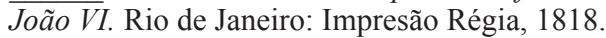

MACEDO, José Agostinho de. Obras inéditas: censuras a diversas obras, 1824-1829; composições líricas, didáticas e dramáticas. Com um breve estudo sobre a história da censura official por Theophilo Braga. Lisboa: Academia Real das Ciências, 1901.

MOMIGLIANO, Arnaldo. "Tácito e a tradição taciteana". In: As Raizes Clássicas da Historiografia Moderna. Bauru: EDUSC, 2004. p. 157-185.

NEVES, Lúcia Maria Bastos P. das. Pensamentos vagos sobre o Império do Brasil. In: COSTA, Hipólito José da. Correio Braziliense, ou, Armazém Literário. Edição Facsimilar. São Paulo: Imprensa Oficial do Estado; Brasília: Correio Braziliense, 2002. p. 469-513.

das. Revolução: em busca do conceito no império luso-brasileiro (17891822). In: FERES JÚNIOR, João; JASMIN, Marcelo. História dos conceitos: diálogos transatlânticos. Rio de Janeiro: Puc-Rio, Loyola, Iuperj, 2007. p. 129-140.

OLIVEIRA, Ricardo de. Amor, amizade e valimento na linguagem cortesã do Antigo Regime. Rio de Janeiro, Revista Tempo, v. 11, n 21, p. 97-120, jul. 2006.

PIMENTA, João Paulo G.; ARAUJO, Valdei L. de História (conceito de). In: FERES Júnior, João (Org.). Léxico da história dos conceitos políticos do Brasil. Belo Horizonte: UFMG, 2009. v. 1, p. 119-140.

POCOCK, John. Introdução: O estado da arte. In: . Linguagens do ideário político. São Paulo: EDUSP, 2003. p. 23-62.

. O Estado da Arte. In: . Linguagens do Ideário Político. São Paulo: Edusp, 2003. p. 23-62.

. Barbarism and religion: narratives of civil government. Cambridge: Cambridge University Press, 1999.

SKINNER, Quentin. Interpretation and the understanding of speech action. In:

Visions of Politics: regarding method. Cambridge: Cambridge University Press, $\overline{2006 .}$ p. 103-127.

TENGARRINHA, José. O jornalismo da primeira emigração em Londres. In: COSTA, Hipólito José da. Correio Braziliense, ou, Armazém Literário. Edição Fac-similar. São Paulo: Imprensa Oficial do Estado; Brasília: Correio Braziliense, 2002. p. 219-58. 
VARELLA, Flávia Florentino. Sine ira et studio: retórica, tempo e verdade na historiografia de Tácito. História da Historiografia, n. 1, p. 71-87, ago. 2008.

VARELLA, Flávia Florentino; ARAUJO, Valdei Lopes de. As traduções do tacitismo no Correio Braziliense (1808-1822): contribuição ao estudo das linguagens historiográficas. In: GALERY, Maria Clara Versiani; PERPÉTUA, Elzira Divina; HIRSCH, Irene (Orgs.). Vanguarda e modernismos. São Paulo: Paz e Terra, 2009. p. 239-259.

WEINBROT Howard D. Politics, taste, and national identity: some uses of tacitism in eighteenth-century Britain. In: LUCE, T. J.; WOODMAN, A. J. (ed.). Tacitus and the Tacitean Tradition. Princeton: Princeton University Press, 1993.

Solicitado em 08/10/2009. Aprovado em 19/11/2010. 